\title{
Akses Media dan Perilaku Seksual Pranikah Beresiko Infeksi Menular Seksual (IMS) Pada Siswa SMA di Kabupaten Malang
}

\author{
Rifzul Maulina \\ Politeknik Kesehatan RS dr Soepraoen Kesdam V/Brawijaya, rifzulmaulina3@gmail.com
}

\author{
Zainal Alim \\ Politeknik Kesehatan RS dr Soepraoen Kesdam V/Brawijaya, zainaliem@gmail.com
}

\begin{abstract}
Abstrak
Usia remaja adalah masa dimana terdapat perubahan yang signifikan secara pemikiran, psikologis dan bentuk tubuh.Perubahan yang signifikan ini menyebabkan usia remaja memiliki sifat yang sama yaitu memiliki jiwa ingin tahu yang besar, menyenangi tantangan serta petualangan dan mengarah berani memikul dampak atas perlakuannya tanpa didahului oleh pemikiran yang dewasa. Tujuan penelitian ini adalah untuk mengetahui faktor-faktor lingkungan apa saja yang berhubungan dengan perilaku seksual pranikah beresiko IMS. Penelitian ini merupakan penelitian penjelasan (explanatory research) dengan desain penelitian yang digunakan adalah cross sectional. Sampel dipilih secara random sampling, yaitu siswa sekolah menengah yang meliputi 2 Sekolah Menengah Atas di Kabupaten Malang yang dekat dengan ekslokalisasi sebanyak 318 responden. Variabel penelitian yang diteliti adalah karakteristik responden (umur dan jenis kelamin), sikap orang tua, sikap teman sebaya dan akses media. Instrumen yang digunakan adalah kuesione yang telah teruji realibilitas dan validitas. Analisa data yang digunakan yaitu analisa univariat, bivariat (chi-square), dan multivariat (regresi logistik) Hasil Penelitian menunjukkan variabel yang berhubungan dengan perilaku seksual pranikah remaja berisiko IMS pada responden laki-laki adalah umur $(\mathrm{p}=0,047)$, sikap orang tua $(\mathrm{p}=0,014)$ dan akses media $(\mathrm{p}=0,03)$. Variabel yang paling berpengaruh terhadap perilaku seksual beresiko IMS pada responden laki-laki adalah akses media dengan OR 2,378 yang artinya responden laki-laki dengan tingkat akses media tinggi memiliki peluang 2,3 kali untuk melakukan perilaku seksual beresiko IMS. Bagi orang tua hendaknya selalu memberikan bimbingan yang positif terhadap anak-anaknya agar berperilaku sesuai dengan agamanya.
\end{abstract}

Kata Kunci: akses media, perilaku seksual pranikah

\begin{abstract}
Adolescence is a period where there are significant changes in thought, psychology and body shape. This significant change causes adolescence to have the same nature of having a big soul of curiosity, likes challenges and adventures and leads to dare to bear the impact of its treatment without precedence by mature thinking. The purpose of this study are what environmental factors that correlated premarital sexual behavior at risk for STIs. This research is an explanatory research with a cross sectional study design. The sample was chosen by random sampling, namely high school students which included 2 high schools in Malang Regency close to ex-localization of 318 respondents. Determination of 2 high school research sites due to a small sample. The research variables studied were the characteristics of respondents (age and sex), attitudes of parents, attitudes of peers and media access. The instrument used was a questionnaire. Analysis of the data used is univariate, bivariate (chi square), and multivariate (logistic regression) analyzesThe results showed variables related to premarital sexual behavior of adolescents at risk for STIs in male respondents were age $(p=0.047)$, parental attitudes $(p=0.014)$ and media access $(p=0.03)$. The variable that most influences sexual behavior at risk for STIs in male respondents is media access with OR 2,378, which means male respondents with high media access
\end{abstract}


levels have 2.3 times the opportunity to engage in sexual behavior at risk of STIs. Whereas in female respondents there are no related variables. Suggestions for schools to provide intensive information to students about reproductive health in order to improve teenage understanding.

Keywords: media access, premarital sexual be

\section{PENDAHULUAN}

Usia remaja adalah masa dimana terdapat perubahan yang signifikan secara pemikiran, psikologis dan bentuk tubuh. Hal ini menyebabkan usia remaja memiliki sifat yang sama yaitu memiliki jiwa ingin tahu yang besar, menyenangi tantangan serta petualangan dan mengarah berani memikul dampak atas perlakuannya tanpa didahului oleh pemikiran yang dewasa. Perubahan ini juga diikuti dengan terdapatnya sarana yang ada disekitar remaja untuk memenuhi kebutuhan dan perubahn sifat tersebut. Kondisi seperti ini sering kali menyebabkan pertentangan batin pada diri remaja. Jika keputusan yang dipilih dalam menghadapi pertentangan tidak benar, mereka akan terjerumus ke dalam perilaku beresiko, masalah kesehatan psikosoial dan fisik seumur hidupnya (Ahmadi, 2009).

Sebagian besar remaja mempunyai rasa ingin tahu yang besar dan tinggi (high curiousity). Karena disebabkan memiliki rasa ingin tahu yang besar dan tinggi, remaja condong ingin mencoba dan menjelajahi sesuatu hal yang belum pernah dilakukan atau dirasakan. Remaja pada umumnya ingin mencoba melakukan apa yang biasanya orang dewasa lakukan hal ini didorong oleh keinginan remaja untuk merasakan kegiatan seksual. Minimya pemberian informasi ini membuat remaja mencari tahu dan mencoba sendiri (Tukan, 2010).

Penyampaian informasi masalah seksual merupakan hal yang sangat penting dikarenakan remaja berada dalam potensi seksual yang aktif, disebabkan berhubungan dengan rangsangan seksual yang disebabkan oleh perubahan hormon endokrin serta remaja sering tidak mempunyai informasi yang cukup mengenai aktivitas seksual mereka sendiri (Tukan, 2010).

Hal ini akan membuat berbahaya untuk perkembangan jiwa remaja jika remaja tidak mempunyai informasi serta pengetahuan yang benar. Berdasarkan realita yang ada menunjukkan jika hampir sebagian besar remaja sangat tidak memahami dampak negatif dari perilaku seksual yang remaja lakukan, berdasarkan usia remaja dikategorikan tidak matang apabila melakukan hubungan seksual terlebih lagi jika remaja harus menanggung dampak negatif dari hubungan seksual yang dilakukan remaja (Sarwono, 2014). 
Berdasarkan data salah satu Tim Survei dari Sebaya dan FK Unair pada tahun 2005 di kota Surabaya dari 126 responden yang berusia 19-23 tahun mendapat hasil bahwa $13,5 \%$ responden mengaku pernah melakukan hubungan seks pranikah. Saat tidak ada pasangan untuk melakukan hubungan seks, beberapa di antaranya melakukan dengan PSK. Survei menyebutkan bahwa $45,7 \%$ responden yang ditemui dilokalisasi mengaku pertama kali ketika berusia 16-20 tahun (Asfriyati, 2010).

Hasil penelitian yang dilakukan di 4 kota besar yaitu yaitu Jakarta, Bandung, Surabaya dan Medan pada bulan September 2004 yang dilakukan oleh Synovate Research tentang perilaku seksual remaja menunjukkan bahwa $65 \%$ remaja mendapatkan informasi tentang seks dari teman, $35 \%$ dari film porno dan hanya $5 \%$ dari orang tua. Bahkan 44\% pernah mempunyai pengalaman seks usia 16-18 tahun. Efek sampingdari perilaku seks bebas, setiap tahun diperkirakan ada 2,3 juta kasus aborsi, yang 20\% diantaranya dilakukan remaja, berdasarkan penelitian Perkumpulan Keluarga Berencana Indonesia (PKBI), dan ada $73 \%$ yang melakukan aborsi tidak aman. (Kemenkes, 2013).

Beberapa penelitian yang dilakukan mengenai resiko perilaku seksual remaja diasumsikan ada tiga faktor yang mempengaruhi adanya kekhawatiran terjadinya risiko seksual pada remaja. Pertama, suatu kecenderungan remaja mengalami kematangan seksual lebih awal karena pergaulan sosial yang sangat permisif dan usia pernikahan semakin tertunda karena melanjutkan pendidikan. Selanjutnya yang kedua sebagian besar remaja tidak mengetahui cara mencari informasi yang tepat baik di rumah ataupun di sekolah tentang kesehatan reproduksi. Sangat terbatasnya kemungkinan untuk peluang diskusi tentang kesehatan reproduksi, dan bahkan sebagian besar guru dan orang tua menganggap hal tabu untuk membicarakan tentang seksualitas. Ketiga, perkembangan teknologi informasi dan komunikasi serta arus deras globalisasi mempunyai dampak positif dan negatif.

Dampak negatif dari perkembangan teknologi informasi dan komunikasi diantaranya timbulnya budaya permisif (kebebasan tanpa batas) mengakses media yang bersifat eksploitasi seksual ataupun penyajian kekerasan. Juga berubahnya culture ignore (budaya acuh) sebagai contoh remaja seharusnya mendapatkan informasi yang tepat karena kesibukan orang tua maka upaya pendampingan kurang diperhatikan sehingga informasi yang diperoleh diterima begitu saja tanpa 
pertimbangan informasi tersebut benar atau tidak. (Suryoputro, 2006).

\section{METODE}

Penelitian ini merupakan penelitian penjelasan (explanatory research) dengan desain penelitian yang digunakan adalah cross sectional, penelitian ini hanya dilakukan pada saat bersamaan saja dan satu kali saja. Data dikumpulkan melalui metode kuantitatif. Populasi dalam penelitian ini adalah siswa SMA di Kabupaten Malang sejumlah 1.828 siswa. Sampel dipilih secara simple random sampling dengan membuat gulungan kertas dan memberi label $\mathrm{X}$ sebanyak 318 responden. Variabel bebas dalam penelitian ini adalah Faktor lingkungan meliputi sikap teman sebaya, sikap orang tua, dan akses media sedangkan Variabel terikat dalam penelitian ini adalah perilaku seksual pranikah beresiko IMS.

Instrumen dalam penelitian ini yang digunakan adalah kuesioner yang berisikan pertanyaan tertutup dan sudah dilakukan uji validitas dan reliabilitas. Hasil penelitian dianalisis secara univariat, bivariat, dan multivariat. Analisis bivariat menggunakan chi-square dan analisis multivariat menggunakan regresi logistik untuk mengetahui faktor yang paling berpengaruh terhadap perilaku seksual pranikah beresiko IMS.

\section{HASIL PENELITIAN}

Tabel 1. Distribusi Frekuensi Perilaku Seksual berdasarkan Umur

\begin{tabular}{|c|c|c|c|c|c|c|}
\hline \multirow{4}{*}{ Umur } & \multicolumn{6}{|c|}{ Perilaku Seksual } \\
\hline & \multicolumn{3}{|l|}{ Laki-laki } & \multicolumn{3}{|l|}{ Perempuan } \\
\hline & Beresiko & \multicolumn{2}{|c|}{$\begin{array}{l}\text { Tidak } \\
\text { Beresiko }\end{array}$} & Bersiko & \multicolumn{2}{|c|}{$\begin{array}{l}\text { Tidak } \\
\text { Beresiko }\end{array}$} \\
\hline & $\%$ & $\mathrm{f}$ & $\%$ & $\%$ & $\mathrm{f}$ & $\%$ \\
\hline $\begin{array}{l}\text { Remaja } \\
\text { Awal }\end{array}$ & $27 \quad 41,5$ & 38 & 58,5 & 2122,1 & 74 & 77,9 \\
\hline $\begin{array}{l}\text { Remaja } \\
\text { Akhir }\end{array}$ & $20 \quad 24,7$ & 61 & 75,3 & $13 \quad 16,9$ & 64 & 83,1 \\
\hline \multirow[t]{2}{*}{ Jumlah } & $47 \quad 32,2$ & 99 & 67,8 & $34 \quad 19,8$ & 138 & 80,2 \\
\hline & \multicolumn{3}{|l|}{$p=0,047$} & $p=0,508$ & \multicolumn{2}{|c|}{ Ho diterima } \\
\hline
\end{tabular}

Berdasarkan tabel 1 menunjukkan bahwa responden laki-laki dengan umur remaja awal ( $<17$ tahun) memiliki perilaku seksual pranikah beresiko (41,5\%) lebih besar jika dibandingkan dengan remaja akhir ( $\geq 17$ tahun) (24,7\%). Hasil uji chisquare menunjukkan bahwa ada hubungan yang signifikan antara umur dengan perilaku seks pranikah beresiko IMS pada responden laki-laki. Demikian juga pada responden perempuan dengan umur remaja awal ( $<17$ tahun) memiliki perilaku seksual pranikah beresiko $(22,1 \%)$ lebih besar jika dibandingkan dengan remaja akhir $(\geq 17$ tahun) (16,9\%).

Tabel 2. Distribusi Frekuensi Perilaku Seksual berdasarkan Jenis Kelamin

\begin{tabular}{|c|c|c|c|c|c|c|}
\hline \multirow{3}{*}{$\begin{array}{l}\text { Jenis } \\
\text { Kelamin }\end{array}$} & \multicolumn{4}{|c|}{ Perilaku Seksual } & \multirow{2}{*}{\multicolumn{2}{|c|}{ Total }} \\
\hline & \multicolumn{2}{|c|}{ Beresiko } & \multicolumn{2}{|c|}{$\begin{array}{l}\text { Tidak } \\
\text { Beresiko }\end{array}$} & & \\
\hline & $\mathrm{f}$ & $\%$ & $\mathrm{f}$ & $\%$ & $\mathrm{f}$ & $\%$ \\
\hline Laki-laki & 47 & 32,2 & 99 & 67,8 & 146 & 100 \\
\hline Perempuan & 43 & 25 & 129 & 75 & 172 & 100 \\
\hline Uji chi suare & \multicolumn{6}{|c|}{$p=0,196$ Ho diterima } \\
\hline
\end{tabular}

Berdasarkan tabel 2 menunjukkan bahwa laki-laki berperilaku seksual 
pranikah beresiko terhadap IMS sebesar $32,2 \%$, sedangkan pada responden perempuan berperilaku seksual pranikah beresiko terhadap IMS sebesar 25\%. Hasil uji chi-square menunjukkan bahwa nilai $\mathrm{p}$ value > 0,05 jadi Ho di terima, sehingga dapat disimpulkan bahwa tidak ada hubungan antara jenis kelamin dengan perilaku seksual pranikah beresiko terhadap IMS pada remaja SMA di Kabupaten Malang.

Faktor Lingkungan meliputi sikap orang tua, sikap teman sebaya dan akses media.

Tabel 3. Distribusi Frekuensi Perilaku Seksual berdasarkan Sikap Orang Tua

\begin{tabular}{lllllllll}
\hline & \multicolumn{9}{l}{ Perilaku Seksual } \\
\cline { 2 - 9 } \begin{tabular}{l} 
Sikap $\begin{array}{l}\text { Orang } \\
\text { tua }\end{array}$ \\
\cline { 2 - 9 }
\end{tabular} & Laki-laki & Beresiko & \multicolumn{1}{c}{$\begin{array}{l}\text { Tidak } \\
\text { Beresiko }\end{array}$} & Bersiko & \multicolumn{2}{l}{$\begin{array}{l}\text { Tidak } \\
\text { Beresiko }\end{array}$} \\
\cline { 2 - 9 } & $\mathrm{f}$ & $\%$ & $\mathrm{f}$ & $\%$ & $\mathrm{f}$ & $\%$ & $\mathrm{f}$ & $\%$ \\
\hline Tidak & 30 & 42,9 & 40 & 57,1 & 13 & 16 & 68 & 84 \\
Permisif & & & & & & & & \\
\hline Permisif & 17 & 22,4 & 59 & 77,6 & 21 & 23,1 & 70 & 76,9 \\
\hline Jumlah & 47 & 32,2 & 99 & 67,8 & 34 & 19,8 & 138 & 80,2 \\
\hline $\begin{array}{l}\text { Uji chi } \\
\text { square }\end{array}$ & $p=0,014$ & Ho diterima & $p=0,335$ & Ho diterima \\
\hline
\end{tabular}

Tabel 3 menunjukkan bahwa responden laki-laki $(42,9 \%)$ memiliki orang tua yang sikapnya tidak permisif, sedangkan pada responden perempuan $(23,1 \%)$ memiliki orang tua yang sikapnya tidak permisif. Mereka yang memiliki orang tua dengan sikap permisif memiliki proporsi melakukan perilaku seksual beresiko IMS. Hasil uji chi-square menunjukkan bahwa pada responden laki- laki terdapat hubungan antara sikap orang tua dengan perilaku seks pranikah beresiko IMS, sedangkan pada responden perempuan tidak ada hubungan antara sikap orang tua dengan perilaku seks pranikah beresiko IMS.

Tabel 4. Distribusi Frekuensi Perilaku Seksual berdasarkan Sikap Teman Sebaya

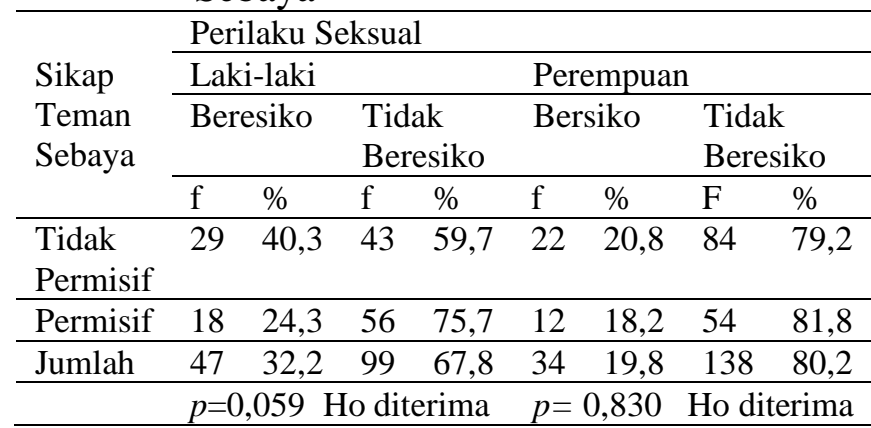

Tabel 4 menunjukkan bahwa responden laki-laki $(40,3 \%)$ dan responden perempuan $(20,8 \%)$ memiliki teman sebaya yang sikapnya tidak permisif. Mereka yang memiliki teman sebaya dengan sikap tidak permisif memiliki proporsi melakukan perilaku seksual beresiko IMS. Hasil uji chi-square menunjukkan bahwa pada responden laki-laki maupun perempuan tidak terdapat hubungan yang signifikan antara sikap teman sebaya dengan perilaku seks pranikah beresiko IMS

Tabel 5. Distribusi Frekuensi Perilaku Seksual berdasarkan Akses Media

\begin{tabular}{|c|c|c|c|c|c|c|c|c|}
\hline \multirow{4}{*}{$\begin{array}{l}\text { Akses } \\
\text { media }\end{array}$} & \multicolumn{8}{|c|}{ Perilaku Seksual } \\
\hline & \multicolumn{4}{|c|}{ Laki-laki } & \multicolumn{4}{|c|}{ Perempuan } \\
\hline & \multicolumn{2}{|c|}{ Beresiko } & \multicolumn{2}{|c|}{$\begin{array}{l}\text { Tidak } \\
\text { Beresiko }\end{array}$} & \multicolumn{2}{|c|}{ Bersiko } & \multicolumn{2}{|c|}{$\begin{array}{l}\text { Tidak } \\
\text { Beresiko }\end{array}$} \\
\hline & $\mathrm{f}$ & $\%$ & $\mathrm{f}$ & $\%$ & $\mathrm{f}$ & $\%$ & $\mathrm{f}$ & $\%$ \\
\hline Rendah & 24 & 41,4 & 34 & 58,6 & 12 & 18,2 & 54 & 81,8 \\
\hline Tinggi & 23 & 26,1 & 65 & 73,9 & 22 & 20,8 & 84 & 79,2 \\
\hline \multirow[t]{2}{*}{ Jumlah } & 47 & 32,2 & 99 & 67,8 & 34 & 19,8 & 138 & 80,2 \\
\hline & \multicolumn{4}{|c|}{$p=0,030$ Ho diterima } & \multicolumn{2}{|c|}{$p=0,830$} & \multicolumn{2}{|c|}{ Ho diterima } \\
\hline
\end{tabular}


Tabel 5 menunjukkan bahwa responden laki-laki $(41,4 \%)$ memiliki akses media rendah, sedangkan pada responden perempuan $(20,8 \%)$ memiliki akses media tinggi. Hasil uji chi-square menunjukkan bahwa pada responden laki-laki ada hubungan antara akses media dengan perilaku seks pranikah beresiko IM.

Dari hasil penelitian variabel yang memiliki hubungan yang signifikan terhadap variabel dependen pada remaja laki-laki adalah umur $(\mathrm{p}=0,047)$, sikap orang tua $(\mathrm{p}=0,014)$ dan akses media $(\mathrm{p}=0,03)$. Sedangkan pada responden perempuan adalah tidak ada variabel yang berhubungan. Variabel yang paling berpengaruh terhadap perilaku seksual beresiko IMS pada responden laki-laki adalah akses media dengan OR 2,378 yang artinya responden laki-laki dengan tingkat akses media tinggi memiliki peluang 2,3 kali untuk melakukan perilaku seksual beresiko IMS.

\section{PEMBAHASAN}

\section{Umur}

Sampel dalam penelitian ini adalah siswa yang sedang duduk di bangku SMA kelas 1, 2, dan 3 yang berusia 15 - 18 tahun. Berdasarkan umur, responden yang termasuk dalam kategori umur remaja awal (<17 Tahun) sebanyak 50,3\% sedangkan umur remaja akhir ( $\geq 17$ Tahun) sebanyak 49,7\%. Menurut Kemenkes (2011) bahwa usia 17 tahun merupakan masa remaja akhir dan selanjutnya akan masa dewasa Jadi, responden dalam penelitian ini adalah remaja yang berada pada masa remaja awal dan remaja akhir, yang duduk di bangku SMA. Pada masa ini remaja masih mencari identitas diri.

Pada saat usia remaja seharusnya remaja sudah memahami tentang seksualitas adalah hal yang merupakan upaya untuk membentuk identitas yang bagus dan tidak labil, karena dengan identitas yang bagus dan tidak labil sebagai makhluk seksual, setiap orang juga paham tentang sikap, keyakinan, batasan-batasan, nilai-nilai yang sudah dimiliki. (Mutia, 2008)

Hasil uji chi-square menunjukkan bahwa pada responden laki-laki ( $p$ value $=0,047$ ) ada hubungan yang signifikan, sedangkan pada responden perempuan ( $p$ value $=0,508)$ tidak ada hubungan yang signifikan antara umur dengan perilaku seks pranikah beresiko IMS.

Hal ini disebabkan bahwa responden pada penelitian ini mempunyai rentang umur yang sangat bervariasi sehingga mempunyai cara pandang yang berbeda dalam menyikapi dan berperilaku terhadap seksualitas. Selain itu, dengan usia menstruasi yang dini saat ini menyebabkan umur menjadi lebih cepat dewasa, sehingga apabila tidak mampu mengendalikan 
dorongan seksual yang muncul, mereka dikhawatirkan akan melakukan perilaku seksual pranikah, mulai dari masturbasi hingga intercourse. (Notoatmojo, 2003)

\section{Sikap Orang Tua}

Hasil penelitian menunjukkan bahwa responden yang melakukan intercouse multipartner bahwa responden laki-laki $(42,9 \%)$ memiliki orang tua dengan sikap tidak permisif, sedangkan pada responden perempuan $(23,1 \%)$ memiliki orang tua yang sikapnya permisif. Mereka yang memiliki orang tua dengan sikap permisif memiliki proporsi melakukan perilaku seksual beresiko IMS. Hal ini dikarenakan responden laki-laki dan responden perempuan memiliki efikasi diri rendah. Hasil uji chi-square menyatakan bahwa pada sampel laki-laki ( $p$ value $=0,014)$ menunjukkan bahwa ada hubungan antara sikap orang tua dengan perilaku seksual pranikah beresiko IMS, sedangkan pada responden perempuan ( $\mathrm{p}$ value $=0,335)$ tidak ada hubungan yang signifikan antara sikap orang tua dengan perilaku seks pranikah beresiko IMS.

Keluarga yang sehat mampu memberikan fungsi secara maksimal dan optimal serta membantu remaja agar bisa mengalihkan dorongan seksual secara produktif dengan cara sesuai dengan nilai yang berlaku serta selaras dengan norma yang ada, hal ini merupakan hasil dari penelitian PKBI (Djoerban, 2009)

\section{Sikap Teman Sebaya}

Hasil penelitian ini menunjukkan bahwa responden yang melakukan intercourse multipartner, bahwa responden laki-laki (40,3\%) dan responden perempuan (20,8\%) memiliki teman sebaya yang sikapnya tidak permisif. Mereka yang memiliki teman sebaya dengan sikap tidak permisif memiliki proporsi melakukan perilaku seksual beresiko IMS. Hasil uji chi square menunjukkan bahwa pada responden laki-laki ( $p$ value $=0,059)$ maupun responden perempuan $(p$ value $=0,830$ ), tidak ada hubungan antara sikap teman sebaya dengan perilaku seks pranikah beresiko IMS.

Pada masa perkembangan, proses remaja adalah masa dimana remaja mulai belajar sosialisasi dan belajar mandiri keluar dari keluarga. Beberapa sifat remaja yaitu dengan membentuk kelompok sosial yang terdiri dari teman-teman terdekatnya, sehingga memiliki rasa yang dapat diterima oleh golongannya dan hal ini merupakan suatu hal yang sangat penting pada saat usia remaja (Nugrahawati, 2016).

Sehingga remaja akan mengupayakan agar bisa diterima oleh kelompok sosialnya dengan berbagai cara diantaranya mengikuti perilaku, nilai dan sikap kelompoknya Meskipun remaja sudah 
dalam tahap perkembangan kognitif yang memadai sehingga dapat menentukan perbuatannya sendiri, namun perilaku remaja untuk menentukan jati dirinya banyak dipengaruhi oleh lingkungan salah satunya adalah teman sebayanya (Asfriyati, 2010).

Komunitas teman sebaya remaja dapat diakui mempengaruhi keputusan serta pertimbangan seorang remaja tentang sikap dan perilakunya. Komunitas teman sebaya adalah sumber rujukan penting bagi remaja dalam hal sikap dan persepsi tentang gaya hidup remaja. Untuk remaja, teman sebaya merupakan sumber informasi misalnya tentang kehidupan seharihari.(Mutia, 2008)

\section{Akses Media}

Akses media adalah berbagai media informasi tentang kesehatan reproduksi, seksual dan pornografi yang pernah dibaca, didengar ataupun dilihat oleh responden. Hasil penelitian menunjukkan bahwa responden yang melakukan intercourse multipartner bahwa responden laki-laki (41,4\%) memiliki akses media rendah, sedangkan pada perempuan $(20,8 \%)$ memiliki akses media tinggi. Hasil uji chi square menunjukkan bahwa pada responden laki-laki ( $\mathrm{p}$ value $=0,030)$ dan perempuan $(\mathrm{p}$ value $=0,830)$, menunjukkan untuk laki-laki ada hubungan antara akses media dengan perilaku seks pranikah beresiko IMS. Sehingga ada kecenderungan responden dengan akses media tinggi juga memiliki proporsi melakukan perilaku seksual beresiko IMS.

Hal yang bisa mempengaruhi terhadap keinginan remaja untuk berperilaku seksual diantaranya adalah buku dan meja berdasarkan Leaner dan Spainer. Pada era saat ini yaitu dengan adanya teknologi yang sangat canggih menyebabkan informasi terkait seks mudah ditemui sehingga bisa menyebabkan dapat memberikan rangsangan secara visual (Mamahit, 2000). Sehingga remaja dalam masa ini ingin mengetahui dan ingin mencoba menirukan apa yang didengarkan dan apa yang dilihat dari media massa yang pernah diakses (Suryoputro, 2006).

Dengan demikian, remaja yang sedang dalam periode ini ingin mengetahui akan mencoba menirukan apa yang dilihat dan apa yang didengarnya dari media massa. Hal ini disebabkan karena remaja merasa aneh dan tidak nyaman sehingga tabu untuk membicarakan tentang seksualitas dan kesehatan reproduksinya sehingga remaja berinisiatif sendiri untuk mencari informasi salah satunya yaitu lewat media massa dimana informasi tersebut belum sepenuhnya benar (Bandura, 1997).

Remaja seringkali merasa tidak nyaman atau tabu untuk membicarakan masalah seksualitas dan kesehatan reproduksinya. Akan tetapi karena faktor keingintahuannya mereka akan berusaha 
untuk mendapatkan informasi ini. Seringkali remaja merasa bahwa orang tuanya menolak membicarakan masalah seks kemudian mereka akan mencari alternatif sumber informasi lain seperti teman atau media massa (Kemendiknas, 2019).

\section{SIMPULAN}

Responden laki-laki dengan umur remaja awal (<17 tahun) memiliki perilaku seksual pranikah beresiko lebih besar jika dibandingkan dengan remaja akhir $(\geq 17$ tahun). Responden laki-laki berperilaku seksual pranikah beresiko terhadap IMS sebesar $32,2 \%$, sedangkan pada responden perempuan berperilaku seksual pranikah beresiko terhadap IMS sebesar $25 \%$. Responden laki-laki (42,9\%) memiliki orang tua yang sikapnya tidak permisif, sedangkan pada responden perempuan $(23,1 \%)$ memiliki orang tua yang sikapnya tidak permisif. Responden laki-laki (40,3\%) dan responden perempuan $(20,8 \%)$ memiliki teman sebaya yang sikapnya tidak permisif. Responden laki-laki $(41,4 \%)$ memiliki akses media rendah, sedangkan pada responden perempuan (20,8\%) memiliki akses media tinggi.

\section{DAFTAR PUSTAKA}

Ahmadi, H. (2009). Psikologi Sosial. Rineka Cipta. Jakarta. 2009.

Asfriyati, D. (2010). Prilaku Seksual Remaja Surabaya serta Faktor-
Faktor yang Mempengaruhinya .Laporan Penelitian Dosen Muda Universitas Airlangga. Surabaya. 2010.

Dinas Kesehatan Kota Malang. Analisis Situasi IMS, HIV dan AIDS Tahun 2013. (2013). Dinas Kesehatan Kota Malang. Malang.

Direktorat Jenderal Pengendalian Penyakit dan Penyehatan Lingkungan, Kementrian Kesehatan Republik Indonesia.. (2013) Laporan Perkembangan HIV-AIDS Triwulan II 2013. Kementrian Kesehatan Republik Indonesia. Jakarta.

Djoerban, Z. (2009). Membidik AIDS, Ikhtiar Memahami HIV dan ODHA. Galang Press Yogyakarta. Yogyakarta.

Kementrian Kesehatan (Kemenkes) Republik Indonesia. (2011). Surveilans Terpadu Biologis Perilaku (STBP) 2011. Kementrian Kesehatan Republik Indonesia. Jakarta.

Komisi Penanggulangan AIDS Provinsi Jawa Timur (KPAP Jatim). (2013). Kondisi HIV \& AIDS di Jawa Timur s/d Juni 2013. Komisi Penanggulangan AIDS Provinsi Jawa Timur. Surabaya.

Mamahit, E. (2000). Validasi Pemeriksaan Infeksi Menular Seksual secara Pendekatan Sindrom pada Kelompok Berperilaku Resiko Tinggi. Buletin Penelitian Kesehatan. Jakarta.

Mutia, Y. (2008). Perilaku Seksual Beresiko Terkait HIV-AIDS pada Buruh Bangunan di Proyek $P$ Perusahaan Konstruksi $K$ tahun 2008. Universitas Diponegoro . Semarang.

Notoatmojo, S. (2003). Pendidikan dan Perilaku Kesehatan. Rineka Cipta . Jakarta. 
Notoatmojo, S. (2013) Metodologi Penelitian Kesehatan. Rineka Cipta . Jakarta.

Nugrahawati, E. (2016). Profil Teman Sebaya, Religiusitas, dan Perilaku Seksual Pranikah pada Mahasiswa. Universitas Islam Bandung. Bandung.

Sarwono, S. (2014) Psikologi Remaja. Raja Grafindo Persada . Jakarta.

Suryoputro, A;. Faktor-Faktor yang Mempengaruhi Perilaku Seksual Remaja di Jawa Tengah. Implikasinya terhadap Kebijakan dan Layanan Kesehatan Reproduksi. Makara, Kesehatan Vol. 10, No. 1, Juni, 2006. 29-40.

Tukan, J. (2010). Etika Seksual dan Perkawinan. Intermedia. Jakarta. 